\title{
Pierre Pech, 1999, Géomorphologie structurale
}

Paris, A. Colin, coll. Synthèse, Géographie, 96 p.

\section{Henri Rougier}

\section{(2) OpenEdition}

\section{Journals}

Édition électronique

URL : http://journals.openedition.org/rge/4258

DOI : $10.4000 /$ rge.4258

ISSN : 2108-6478

Éditeur

Association des géographes de l'Est

Édition imprimée

Date de publication : 1 janvier 2000

ISSN : 0035-3213

Référence électronique

Henri Rougier, "Pierre Pech, 1999, Géomorphologie structurale », Revue Géographique de l'Est [En ligne], vol. 40 / 1-2 | 2000, mis en ligne le 07 août 2013, consulté le 22 septembre 2020. URL : http:// journals.openedition.org/rge/4258; DOI : https://doi.org/10.4000/rge.4258

Ce document a été généré automatiquement le 22 septembre 2020.

Tous droits réservés 


\section{Pierre Pech, 1999, Géomorphologie structurale}

Paris, A. Colin, coll. Synthèse, Géographie, 96 p.

Henri Rougier

\section{RÉFÉRENCE}

Pierre Pech, 1999, Géomorphologie structurale, Paris, A. Colin, coll. Synthèse, Géographie, $96 \mathrm{p}$.

1 Comme bien d'autres titres parus dans cette collection, celui que nous livre présentement Pierre PECH est d'un grand intérêt. Sur un sujet qui a été si souvent et très exhaustivement traité, il n'était sans doute pas évident de parvenir à rassembler en peu de pages et d'une manière aussi simple que possible l'intégralité des données et des problèmes, dans le but de les faire acquérir sous forme de bases par des étudiants débutants ou par d'autres désireux de réviser leurs connaissances élémentaires. Quatre grandes subdivisions font découvrir la terre et sa composition, les roches, les reliefs et les déformations tectoniques, les ensembles structuraux. Dans chacun de ces grands chapitres, l'auteur dont le style est sobre et sans fioriture, décrit et explique l'essentiel et accompagne le plus souvent son texte de schémas très simples mais parfaitement cohérents.

2 Tenant compte des objectifs que se fixe la collection, il nous apparaît que la mission à laquelle s'astreint l'ouvrage de $\mathrm{P}$. PECH est très bien remplie. C'est pourquoi nous recommandons vivement sa lecture aux étudiants qui débutent ainsi qu'à tous ceux qui souhaiteraient remettre à niveau ou seulement vérifier leurs connaissances sur cette noble branche de la géographie. 


\section{AUTEURS}

HENRI ROUGIER

Université de Lyon 3 